\title{
MASCULINITIES IN FORESTS
}

\section{Here and there, then and now}

Born in suburban Chicago, raised in the cornfields of the Midwest and the arid plateau of Ankara, Turkey, still I have loved forests since I first encountered them. Beautiful images, tinged with the frisson that accompanies real adventure, come to mind as I consider my topic here:

Driving up the eastern shore of the Olympic Peninsula in the North American State of Washington. To my right is Hood Canal, an offshoot of salty Puget Sound; to my left are the magnificent snow-covered Olympic Mountains, their foothills covered in tall and stately evergreen forests-hemlock, pine, cedar, Doug fir, small streams breaking any possible monotony, herds of elk browsing in the area cleared for power lines.

Later in Borneo, the weather is warm and the trees are again evergreen, but different species: Dipterocarpus, Dryobalanops and Shorea, majestic species like Koompassia excelsa, and iron-hard ones like Eusideroxylan zwageri. I sit in a canoe, navigating a narrow freshwater stream, foliage bending over us, creating a green tunnel through which we manoeuvre. The paddles gently break the water, gibbons call to each other in the early morning hours.

On another journey further inland, I'm taken by canoe to report to local officials. The young Kenyah men kindly and energetically pole me upstream, over fast and noisy rapids, their bare muscles bulging in the sunlight, straining against the water's power with all their might. We pass various patches of forest-old growth, young and old secondary regrowth and swidden rice fields here and there.

Yet again, I go with a log truck driver into the forest to watch American logging in the 1970s. The logger drives the huge log truck up dirt roads, through dense forest, past clear cuts and replanted areas with trees of varying ages and heights. I am entranced by the habitat ${ }^{1}$ and intrigued by these men who value their own strength and their outdoor profession so highly. As a feminist, I am 
part repelled by the inherent sexism, part attracted. As others have noted, these men are sexy in their 'in-your-face' masculinity:

Let me tell you about loggers. I married one 18 years ago. I couldn't resist the smell of utter maleness in damp, sweaty black wool underwear sweetened by the heavy scent of fresh sawdust and chainsaw exhaust . . . I still love the romance of big men, big machines and big trees . . Loggers are the last of a dying breed of men who "work" for a living. Their work is dangerous and back breaking . . . [An environmentalist] should try hugging a logger-she'll never go back to trees!

(Maureen Henderson, Chilliwack Times, 1993, $p$ 9) ${ }^{2}$

Here, I hope to take you on a journey to five 'spaces':

- The America of my childhood, from Maine through the Midwest to the Pacific Northwest

- The forests of America's Pacific Northwest in the mid-1970s

- The wilds of Borneo in the early 1980s

- The somewhat more domesticated forests of West Sumatra in the mid-1980s, and

- The world of international conservation and development from the 1980 s to the 2010s.

I then add an update on the rural US and Borneo more recently to see how these worlds of men and forests have changed.

My hope is that by visiting these spaces, we can see first how masculinities interact with forests and forest management, and how forest managers can manage forests better based on such knowledge. Secondly, I hope that my conceptualization of cultural stability and men's agency, in interaction, can cast light on ordinary men's lives in their various contexts - contributing also to gender studies.

In my professional life, I paid a lot of attention to women. But a few years back, I began to feel a sense of malaise. We said we were looking at gender, ${ }^{3}$ whereas in reality mostly we were looking at women's worlds. I began to wonder about men's worlds. As I read the very different body of literature called 'masculinity studies' the seeds for this book were planted. The ideas took hold and grew.

My desire to share my findings with gender and masculinity scholars on the one hand and biophysical scientists (foresters, ecologists, natural resource managers) on the other, creates problems (epistemological, evidentiary and in terms of vocabulary). I address this problem by providing warning, in footnotes if not clear from subtitles, regarding sections of greater or lesser interest to one or another group of readers.

One impetus to writing this book was my initially unreasoned resistance to the phrase 'hegemonic masculinity'-once so common in masculinity studies. ${ }^{4}$ 
Although I recognized that men have advantages related to power, apparently in all cultures, the rationales for such advantages were too variable to be considered globally 'hegemonic', and I wasn't sure one could always identify one version even as locally hegemonic everywhere either. ${ }^{5}$ Men, their behaviour and the norms that influenced them, varied enormously from place to place, and even man to man. Over time, I also realized that writings about hegemonic masculinity were shifting to a focus on masculinities, plural. I began to interrogate my ethnographic experience, much of which has been in forests, settings typically considered masculine. Forests are the domain of logging and timber production, heavy equipment and international markets, and the field of forestry has been dominated by such stereotypically male concerns. Although much of my professional life has been devoted to demonstrating women's presence, interests and activities in forests, I realized that I also knew quite a bit about what men do in forests and among the forest peoples I know well.

I'd also read books and articles on masculinity over the years and came away with the disappointing feeling that this literature focused almost exclusively on problems with masculinity. ${ }^{6}$ There was an inordinate amount written on domestic abuse, HIV/AIDS, warfare and homosexuality (the last no longer seen as problematic itself, though often spelling problems for those so inclined).

In late 2017, I began to dip methodically into such studies. I found more varied literature that dealt with a wider spectrum of men's lives than I had hitherto seen. There remained a clear urban bias though in many studies, as well as an emphasis on nonconventional sexuality. I knew from my research and life experience that men's lives were not composed only of problems, that men-ordinary heterosexual men - had strengths and contributions to make in family and community life. ${ }^{7}$ I also had seen the incredible variety in ideals of manhood, in its practice and in men's goals and interests. This book represents an attempt toward 'righting the balance' and sharing what I know of the lives of predominantly heterosexual men in rural, particularly forested, places.

Little (2006) and Pini, Brandth and Little (2015) point out the paucity of rural studies generally, an observation even more cogent for the topic of masculinities in forests. In this book, I reflect on the variety of masculinities I encountered, primarily in three rural, forested contexts - all areas where I lived, doing ethnographic research over long periods of time. I then turn to the international research world, from which forest-related research is routinely conducted, examining notions of masculinity among elites.

Much of the masculinity literature (with a few notable exceptions) is written by men about men, just as gender materials on women are often written by women. In trying to achieve a more balanced view of men's and women's lives, I look here at men through an American woman's eyes. As in Enria's (2016) work, masculinity has not been the primary focus of my research. What I present here represents a mining of my ethnographic experience, which inevitably included both men's and women's beliefs, behaviour and goals. This 'excavation' uncovered useful understandings of men's lives. 
Keeler (2017) warns us that the assumptions that westerners, devoted to egalitarian ideals, hold can prevent them (us) from seeing hierarchies assumed by others (in his case, the Burmese). Similarly, as a woman with what might be a 'womanly' world view and set of assumptions, I may be blind to assumptions men hold; I cannot know what is in the hearts of men. Yet I can observe and see the effects of what is in their hearts. And I can make educated guesses about what such actions imply — as I do when trying to understand and convey the meanings and actions of the Kenyah or the Minangkabau in Indonesia or a to-me-oncealien American subculture.

Partly because of these uncertainties, I present an account of these ethnographic experiences with a reflexive bent, one that both recognizes my own positionality and considers the effects of the passage of time, my own aging process and likely influences on my observations and interpretations. ${ }^{8}$ I approach this task by taking the reader on a journey through space and time-linking my own life journey with the passage of time and travel through space.

\section{Masculinities and forests}

But what does all this have to do with forests? Most fundamentally, the general agreement that forests are 'masculine contexts', at least in the international world of conservation and development, suggests that we might want to know more about this defining quality. What are the implications of masculinities in forests? How do they play out in different contexts? How do men's relations with forests differ from women's?

I agree with Paulson (2016), who has encouraged us to look more carefully at the various masculinities extant in particular geographic spaces. She says,

The processes of becoming, and the practices of . . . [a particular identity]. ${ }^{9}$. . . depend not only on intersubjective relations with people in similar and different positions within a social system but also on relations in and with the biophysical space that has been shaped by, and that works to reproduce, those social systems.

Forests are one such biophysical space.

In the coming chapters, I look at the elements of masculinities that men in these different contexts, times and ages choose from among the structured options available to them. The emphasis in many, though not all, contexts on men-as-providers suggests implications for forest-based activities. Men may be more likely to view forests as potential sources of income than women (as some studies have shown). Some men may value the forest primarily for its products (e.g., Sitiung, Chapter 5). The devotion to an outdoor life as an indicator of manliness may give forests special meaning to men in some communities (e.g., Bushler Bay loggers, Chapter 3). The desire to demonstrate physical strength 
may be a factor in some men's desires to remain in logging, even when formal management goals have shifted to another use. The imperative to demonstrate courage can be another motivator to work in the woods (e.g., Chapters 3 and 4, on Borneo's Kenyah). Emphasizing control and articulateness, as some elite men do (Chapter 6), can have adverse implications for their ability to hear what local communities desire and know.

Men's ideas about their own identities and related practices are important to forest management insofar as the forestry world is committed to taking human beings into account - a commitment that has only grown in recent years. There have been increasing attempts, for instance, to involve local communities in collaborative management (building on works such as CIFOR's Adaptive Collaborative Management Program, e.g., Colfer 2005; or more recently, in relation to REDD+, Larson et al. 2016). Extractive studies ${ }^{10}$ of forest use are also common, but generally without attention to people's ideas about what a good man is or should be (cf. Petesch et al. 2018; Elias et al. 2018, for counter-examples) something that can influence what men want, need and are willing to do in forests.

Forest policy development could also benefit from a better understanding of the varieties of ways men interact with and value (or disvalue) forests. If local people link men's masculinities primarily to provisioning from the forest as a source of products (and women do not have other important uses), the development of economic alternatives like agriculture as the forest disappears may be a good policy option. However, if local men's identities are tightly bound up with the forest $\mathrm{t}^{11}$ — whether to protect it, recreate in it, or harvest it — then a policy that switches management from timber to oil palm, for instance, will cause more personal and cultural dislocation (Colfer 2018). Similarly, decisions to resettle men who have strong links to forests to an agricultural or urban landscape will engender a serious sense of loss. For those with fewer direct forest-culture connections, the pain associated with such a move may be far less.

Besides the value for foresters, these studies contribute to our social scientific understanding of gender, something we (gender specialists) have approached in a one-sided manner, often examining only women's lives, as noted earlier.

\section{What kinds of forests?}

The term 'forest' can be interpreted in a variety of ways, including even as a previously forested area. A commonly used definition is that of the Food and Agriculture Organization (FAO):

Forest includes natural forests and forest plantations. It is used to refer to land with a tree canopy cover of more than 10 percent and area of more than 0.5 ha. Forests are determined both by the presence of trees and the absence of other predominant land uses. The trees should be able to reach a minimum height of $5 \mathrm{~m}$. Young stands that have not yet but are expected to reach a crown density of 10 percent and tree height of $5 \mathrm{~m}$ are included 
under forest, as are temporarily unstocked areas. The term includes forests used for purposes of production, protection, multiple-use or conservation (i.e. forest in national parks, nature reserves and other protected areas), as well as forest stands on agricultural lands (e.g., windbreaks and shelterbelts of trees with a width of more than $20 \mathrm{~m}$ ), and rubberwood plantations and cork oak stands. The term specifically excludes stands of trees established primarily for agricultural production, for example fruit tree plantations. It also excludes trees planted in agroforestry systems.

(www.fao.org/3/Y1997E/y1997e1m.htm\#bm58\}, accessed 14 June 2019)

The Center for International Forestry Research in Bogor initially found the concept of forest so slippery that its leaders agreed not to define it. My silviculturist colleague, Ravi Prabhu, suggested (and we adopted) the following usage for our work on criteria and indicators for sustainable forest management in the 1990s: We differentiated a 'forest rich' environment, which was 'islands of people in a sea of forest' from a 'forest poor' environment, 'islands of forest in a sea of people' (Colfer and Byron 2001, p. 28). I continue this usage in this book. Unlike FAO, I explicitly do include here forest fallows that are part of swidden agroforestry systems (e.g., in Chapters 4 and 5) and do not include oil palm plantations (especially Chapter 7).

The idea of a landscape mosaic is another useful concept. It recognizes that forests are part of broader landscapes that may be composed of varying land uses, such as old growth, secondary and degraded forests, grassy areas, villages (and villagers), agriculture, roads and infrastructure (e.g., Mertz et al. 2012; Sayer et al. 2013; and the collection by Colfer and Pfund 2011).

The masculinities examined in this book were associated with areas where old growth dominated when the research began (1975 on Washington State's Olympic Peninsula, 1979 in East Kalimantan and 1983 in West Sumatra). Recently (2017) on the Olympic Peninsula, replanted forests predominate, with some old growth; and in 2019, in East Kalimantan, oil palm predominates, with secondary forest/agroforestry mosaics only near rivers' edges (see Figure 1.1).

My emphasis on reflexivity as essential in this book's 'journey' has meant the inclusion of some experiences and research in predominantly arid (Turkey, Oman), agricultural (the American midwest) and urban (Indonesia, US) areas, as well as occasional reference to masculinities in forests in Europe and tropical Africa, Latin America and other areas of Indonesia. I provide snapshots of typical forests, as they are encountered, in each setting discussed.

\section{Framing of masculinities}

As I analyzed my observations on masculinities in different contexts, I grew increasingly dissatisfied with the ways masculinities had been conceptualized in the literature (e.g., too focused on problems, biased toward atypical sexualities, overly influenced by western ideas about gender). I wanted to capture the 


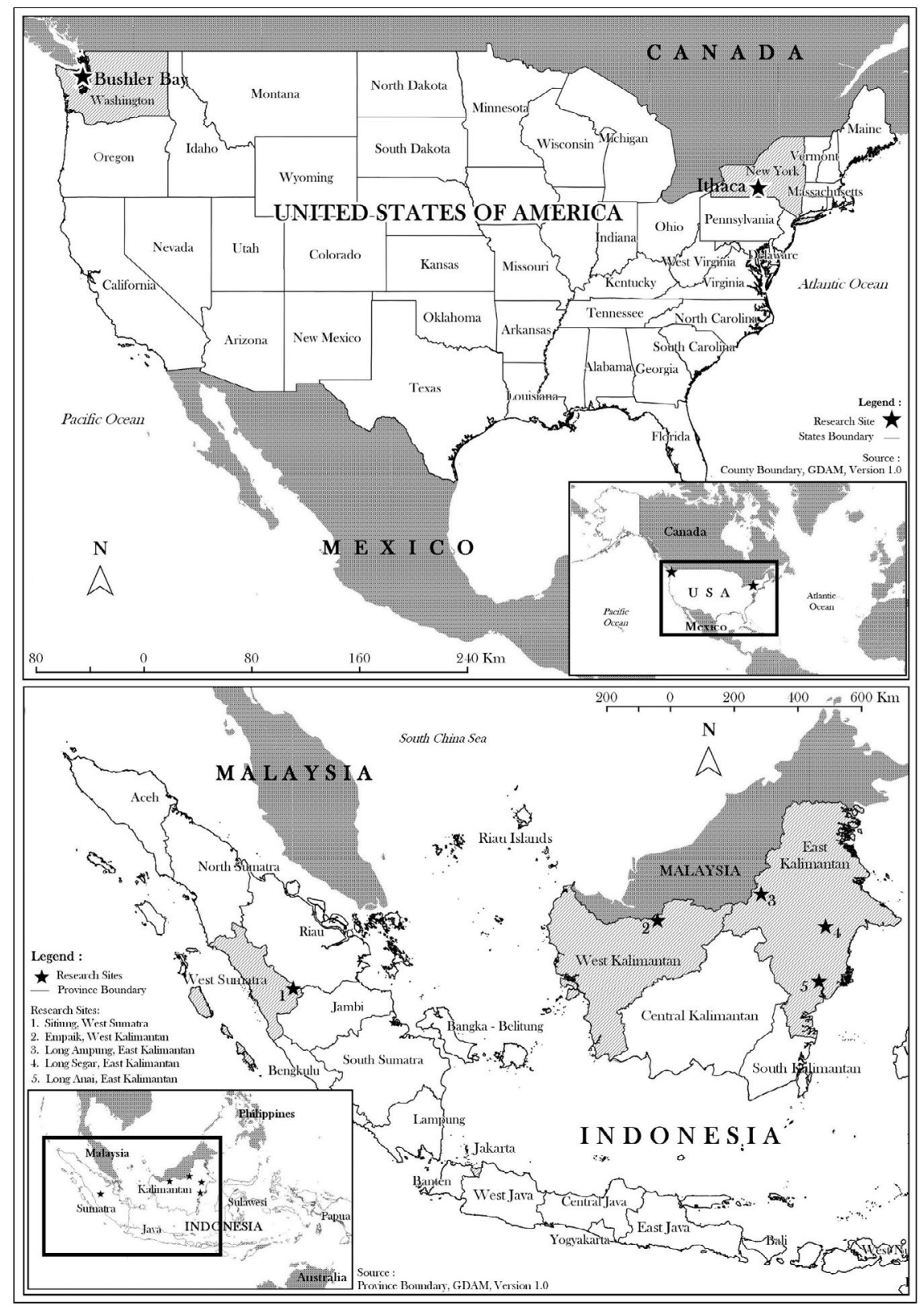

FIGURE 1.1 The research sites discussed in this book. 
variety, the stability of cultural systems and the choices available to individual men in terms of their own identities. While considering these issues, I read Spiller's book Erotic Triangles. Erotic Triangles focuses very tightly on the role of dance in Sundanese ${ }^{12}$ men's sense of their own masculinity. Although forests are not mentioned in his book, the Sundanese are sometimes referred to as 'mountain people', and much of their world is indeed forested. Spiller argued that masculinity among the Sundanese could be presented as a triangle, with one side of the frame the dancing men, the second side the ronggeng (a beautiful woman seen as part whore, part goddess) and the third side, the drummer who sometimes leads, sometimes follows the dancing men's creative yet constrained lead.

\section{The harp: its structure, context and change}

Here I ask the readers' forbearance, as I put forth my unusual approach. I have adopted Spiller's idea of a triangle, a constraining boundary, representing a cultural complex of ideas and practices pertaining to masculinities. I began to think of this triangle as being like a harp, from which men ${ }^{13}$ could choose first, sets of strings (qualities, interests, norms) that form chords (bundles or clusters of strings, linked qualities/preoccupations), and eventually the 'song' that represents a given man's version of masculinity within his own life-represented on the cover of this book. The harp itself represents the stability and constraints that cultures provide, and the strings represent the elements of choice for individuals, with some chords dominant (more highly valued) within a given culture.

In modern times, a harp is an unusual analogy for a study of masculinities, given its feminine connotations in the West/North. ${ }^{14}$ However, my hope is that this concept, slightly jarring to westerners, can help to remind the reader that we are looking at masculinity through a [this] woman's eyes-one important way to see masculinities in our hunt for understanding of gender dynamics.

Deciding to use this analogy derives from a problem all gender scholars have: How to acknowledge the stability that a bio-socio-cultural system maintains, its coherence and resistance to changes in many spheres of life, with the fact that nonetheless cultures do change, sometimes very quickly, and that individuals have equally obvious agency. The 'normative climate' proposed by Petesch et al. (2018) captures some of the stability of the harp, but here I'm seeking a clearer mechanism by which to reflect agency. Some normative climates are more open to experimentation and thus more conducive to an agency that not only struggles against constraints (as characterize many of the examples in Petesch et al.). ${ }^{15}$ cultural harps also provide opportunities for agency, to varying degrees for both men and women.

Men, like women, are constrained by the choices and structures available locally, just as a harp constrains what music one can produce in a very general way. A Kenyah Dayak did not, until quite recently, have the option to be an academic scholar; an American logger would not likely have the option to take up Sundanese dance. But within the repertoire available, there can be considerable 
freedom to fashion one's identity and one's life. The amount of such freedom also differs from one culture to another. Connell (1995) and Pascoe (2007) for instance, show the formidable pressures American cultures can bring to bear in enforcing heteronormativity. ${ }^{16}$ Paulson (2016) shows the system-based oppression inherent to interactions between some Latin American masculinities. Sutlive's (1991) collection on Borneo presents contexts far more conducive to men's experimentation with varying identities than do these examples.

One's choices have different implications for prestige within different groups of like-minded folks; the American village discussed in Chapter 3, for instance, included two groups or subcultures in the 1970s ('Locals' and 'Public Employees', Colfer and Colfer 1978). The son of a logger (a 'Local') on Washington State's Olympic Peninsula would have reaped disdain from his parents and their friends if he had opted to become a school teacher; this profession was seen locally as unmanly and marked by low salaries. In the same community, the son of a school teacher, a 'Public Employee', would have been-indeed, still would be-discouraged from becoming a logger, a profession seen by Public Employees as insecure and low status.

Different career choices there tended to imply different clusters of valued qualities. A logger, for instance, could pluck one set of strings symbolizing physical strength, practical skills, a love of heavy equipment and courage, and another set of strings related to independence and control in his home life, thereby creating his own song of manhood. A school teacher's song could be created from strings symbolizing academic knowledge, punctuality and security, on the one hand, and companionate marriage and being a responsible breadwinner on the other. But these are just 'ideal types'; any individual man can vary his choice of strings, with fairly predictable implications for his prestige within this or that group. A logger without physical strength, courage or practical skills could expect to be disdained; whereas a school teacher without those qualities would suffer far less. Conversely, a teacher whose academic knowledge was perceived to be inadequate may not have been tolerated, whereas a logger with this 'deficiency' would have been comparatively unaffected. Sometimes strings are plucked with forethought, a lifetime of commitment to that string, and/or full awareness of its implications for status and identity. Other times, people may act 'on the fly', without such forethought and with unpredictable effects. Still other times, one can imagine that a man might make conscious decisions to alter his identity and pluck a particular string accordingly, come what may. ${ }^{17}$

Since different groups assign different values related to the perceived masculinity of different qualities, one might cluster those qualities most closely aligned with masculinity within a given group, as the deeper tones of the harp, perhaps where the strings are longer and made of heavy wire rather than catgut. I focus in this book on the selection of harp strings, leaving the more complex chords and songs for future analyses.

In contexts where femininity is seen as the opposite of masculinity, qualities perceived to be feminine could be placed at the higher tones. This is, however, 
not a universal opposition (see Chapter 4); gender polarity is only perceived among some groups. Paulson (2016) agrees. Her thoughts on the power behind northern views are germane:

Lugones [2007] urges readers to recognize that biological dimorphism, woman/man dichotomy, heterosexualism and patriarchy are not universal features of human social life but historically specific manifestations of one model-that which she calls the 'modern/colonial gender system'.

The hegemonic power of this model is rooted in the interdependent development of colonial/modern gender systems and colonial/modern sciences that built a powerful association between a particular binary organization of gender and biological understanding of the sexual dimorphism of Homo sapiens. In the realm of gender, like that of race, the establishment of a knowledge/ideology that construes the dominant cultural order as biologically determined has proven extremely effective in leading actors to perceive that particular cultural order as inevitable and universal.

This book strives to incorporate greater attention to change, ${ }^{18}$ as well as stability. Over the course of my lifetime (and in the material in this book) an incredible expansion of communication has occurred. This has expanded awareness, in the most remote parts of the forested world, of different attitudes, behaviours and ideals about masculinity, different 'harps', with a resultant expansion of the strings available locally. Such awareness requires greater attention to the issue of scale.

As early as 1960, Redfield (1960) had identified the relations between what he called the great tradition and the little tradition in peasant societies. ${ }^{19}$

The great tradition is cultivated in schools or temples; the little tradition works itself out and keeps itself going in the lives of the unlettered in their village communities.

(pp. 41-42)

Although many forest communities would not have been considered 'peasants' in anthropological usage at that time, ${ }^{20}$ interactions between small forest communities and such outside influences were already present and have intensified enormously. Rather than one 'great tradition' impinging on people's lives as Redfield observed in Mexico, there are now many, via social media, email, television and radio, reflected in a May 2017 interview with an American 'Local' man from the forest community discussed in Chapters 3 and 7, see p. 324). He explains how social media have widened people's perspectives and acceptance, for instance, about homosexuality.

If we follow the harp analogy, with each community represented by one or more particular 'harp', we can see that people's awareness of harps from other 
contexts has grown exponentially. In Long Segar, East Kalimantan (Chapter 4), even in 1979, the people were exposed directly to masculinity-related influences from the church, the mosque, the government and international private industry - all operating on broader scales, with new ideas and more power, prestige and resources than local people had. ${ }^{21}$ These influences had grown more intense 40 years later, with improved communications and infrastructure. We can consider the harps available-external and local — to constitute an 'orchestra' of harps, which carry the potential to produce beautiful music . . or cacophony.

Other scholars have provided insights of relevance to this book: ${ }^{22}$ Raewyn Connell, one of the earliest and most widely cited of masculinity scholars and the originator of the focus on hegemonic masculinity, has the unique advantage of having looked at masculinities from both a man's and a woman's perspective, having had a sex change late in life. In one of her earlier works (1995), she posits four kinds of masculinity, summarized conveniently by Pascoe (2007):

R. W. Connell argues that men enact and embody different configurations of masculinity depending on their positions within a social hierarchy of power. Hegemonic masculinity, the type of gender practice that, in a given space and time, supports gender inequality, is at the top of this hierarchy. Complicit masculinity describes men who benefit from hegemonic masculinity but do not enact it; subordinated masculinity describes men who are oppressed by definitions of hegemonic masculinity, primarily gay men; and marginalized masculinity describes men who may be positioned powerfully in terms of gender but not in terms of class or race.

(p. 7 , italics in original)

These differentiations are recognizable in some places and times, but not particularly in others. Much of Connell's work is both insightful and fascinating but depends on a social context that strongly differentiates men and women, which is not the case, for instance, in some areas of Indonesia (see e.g., Chapter 4 or 7 , this volume; or Cornwall 2016, more generally). In Chapter 3, we see two versions of what might be termed hegemonic masculinity, operating side by side in the same village. They reflect the ideological struggle over hegemony ${ }^{23}$ discussed by Gramsci, especially in his prison notebooks (Forgacs 2000).

Gibson presents another way of looking at these choices, most clearly in Gibson (n.d.). He documents three different ways, linked to gender, that one can emphasize one's values, motivations and appropriate behaviour among the Makassar of Ara, South Sulawesi. These orientations are linked to the house (built on indigenous social structure), the mosque (linked to Islamic mysticism) or the school (emphasizing the Indonesian nation-state). In Gibson's later work he expands on these as modes of sociality with differing ontologies.

Lentz (2017), building on von Benda-Beckmann's (2009) notion of 'symbolic universes', discusses what appears to be the same three components-termed Traditionalism, Islamicism and Modernism-operative in Sundanese lives (p. 46). 
In my terms, men choosing each of these modes of sociality (or identities or universes) would reflect different chords, or clusters of harp strings. In southern Sulawesi, Graham-Davies (2004) describes local recognition and spiritual relevance of five divergent genders, of particular interest as an intriguing example of the global divergence in forest-based masculinities that I hope to show in this book (see also Gibson 2005).

Gibson (n.d.) notes that "every individual in the world participates in several institutions that operate according to incommensurable forms of temporality, spatiality, subjectivity and authority" (p. 26). He shows the various ways in which local practice brings these divergent ontologies or modes of sociality together (e.g., a religious sheik [Islamic mosque] buried with an aristocratic wife [Austronesian house]). ${ }^{24}$ I take from this observation (though he does not say this) that individuals have differing options or interpretations available to them for potential use in different circumstances. ${ }^{25}$ Where I have referred to 'songs' above, Gibson refers to the internal logic of a given identity as 'grammatical' (or presumably not).

Keeler (2017), another theorist on masculinity, posits a spectrum with autonomy at one end and attachment at the other, which he sees as capturing one of the most fundamental issues that men must resolve in their lives and choices and in their interaction with [the less valued] women. For the Burman monks he worked with, "autonomy constitutes an unrealizable but incontestable goal to which all males should strive[;] it enjoys hegemonic authority" (p. 229). He further links these concepts with sexuality and hierarchy.

I have suggested that autonomy stands at one end of a spectrum that runs between it and attachment, and that this links it to the end of another spectrum that runs between superordination and subordination. In other words, engaging in sex without becoming personally entangled with someone looks like the behavior, or privilege, of the person who enjoys what might be termed, aptly if perhaps coyly, the upper hand: the agent endowed with greater power and superior standing, with greater freedom to maneuver; and so, autonomy.

So to the extent that autonomy constitutes the solution to the dilemma of attachment, and autonomy enjoys a privileged place in hierarchical views of the world, giving up sex has to arouse maximal respect.

So different from the views I've encountered and discuss in the pages to follow! Ford and Lyons (2012), whose collection focuses primarily on urban settings, recognize the varying kinds of masculinity, that these are subject to change and that they are not essential features of men's biology (that women too can manifest features often described as masculine). These authors emphasize the performative rather than essential nature of gender: 
the construction of 'gender' as multiple and variable. Not only does such an approach provide a means to acknowledge female masculinities and male femininities, but it also affords a means to examine how men negotiate masculinities in their daily lives.

This view is consistent with the emphasis here on choice, agency (à la Kabeer 1999) and variability within cultural systems that may provide enough stability for human comfort and predictability.

\section{The ethnographer as interpreter}

In recent decades, as noted earlier, anthropologists have increasingly recognized the significance of their own world views and personal situations in influencing their interpretations of what they see. As a woman considering masculinity, this strikes me as particularly likely to play an important role in what I see, how I analyze it and what I report. Bringing these considerations to the fore, and being so honest about my own sexual involvements (discussed shortly) goes against established practice, ${ }^{26}$ despite postmodern ideas about positionality and its relevance. Altork (1995) and Killick (1995) both address this issue clearly in their analyses based on their respective experiences in the US and Korea. Here I discuss my own peccadillos as well as my interpretation of their relevance for my findings and the ethical implications.

In considering the book, The Wild Man, by Schneebaum (2003)—which reportedly discusses his participation in homosexuality and cannibalism in the field-Altork says,

One can't help but wonder if his writings would have caused more of an uproar if they had not been homosexually contextualized, i.e. if he had had passionate affairs with women 'natives' and written about it as candidly as he wrote about his homo-erotic experiences. It's almost as though he could be written off - the marginal writing about the marginalized-since his behavior didn't involve a cross-gender interaction. This is a sad indictment of one of the ways in which our culture compartmentalizes and privileges certain kinds of experience as being more meaningful and, perhaps, more worthy of being entered into the academic discourse.

This perspective is echoed by Bolton (1995), a gay man, who points out that gay researchers, already marginalized, lose less by discussing taboo subjects. He also argues that "refusing to share in sexuality across cultural boundaries helps to perpetuate the false dichotomy between 'us' and 'the natives"' (p. 140).

When Killick was asked to contribute to Kulick and Willson's (1995) book Taboo: Sex, Identity and Erotic Subjectivity in Anthropological Fieldwork, he was "bemused 
by the prospect of being seen as a 'token' straight white guy" and "puzzled by the task of writing about [his] love life in a way that would be honest and explicit, but would not read as either confessional, pornography, or an extended singles ad" (p. 79). I have struggled similarly.

Feldman and Shaw (2018), writing about the ethics of interpretive ethnography, discuss how "data are intimately tied to the perceptions, experiences, and meaning-making processes of the researcher". They highlight that such an approach

ties data to the immersion of researchers in the everyday lives of those they study and is premised on integration of processes of data production and analysis. In this constitutive framing, the ethnographer is not separate from but, rather, is integrally linked to, and a part of, the story she/he tells.

I have no doubt that my own situations and the choices I've made about sexuality in my various field experiences have had an influence on what I've been able to understand about each version of masculinity. I therefore explain them briefly but honestly here.

My parents went to great effort to avoid inculcating in me any ideas of shame or disapproval of sexuality per se, though they warned me about the dangers of unplanned and premature pregnancy. As several recent feminist authors have argued (e.g., Fine 2010; Saini 2017), scientific interpretations-dominated by men's perspectives - about women's inherent passivity and choosiness in sexual matters have been greatly exaggerated. My own sexuality, particularly during my 20 s and 30 s when the sex drive tends to be particularly powerful, was definitely a force to be reckoned with. Logic and rationality did not always function perfectly when confronted with desire (and in the fieldwork context, curiosity).

In Bushler Bay (Chapter 3), I was in my 20s, sexually switched on, and married with one daughter (aged 3-6). My anthropologist husband and I were both interested in gender roles and in experimenting with both them and our relationship. We married in the 1960s, and by the 1970s, many were similarly experimenting, including with what was then called 'open marriage'. After a couple of years in Bushler Bay-a context where sexuality was ever-present and explosive-we both had sexual relations with another couple (secret from the community but discussed openly among ourselves). We attempted to live communally for a brief time, during which I insisted there be no more cross-couple sexual relations; my [conscious?] reason was that I wanted to be able to deny their existence honestly if community members should ask me about this issue. Jealousy (perhaps predictably) also raised its ugly head. Although there were personal implications for our respective relationships, I doubt that anyone in the community was injured by our experimentation. And I believe that our sexual involvement was helpful in understanding sexuality - a vital part of many men's masculinity - in that community. 
By 1979, that marriage was coming to an end, and I went to Long Segar, East Kalimantan alone. I stayed for 11 months. After about five months, I became secretly sexually involved with my married field assistant, eventually deciding to have a child by him. ${ }^{27}$ This liaison initially involved secrecy, dishonesty, guilt about his wife and several years later being tried and fined locally. Again, although I have regretted the impacts of this relationship on his wife (who eventually forgave me), ${ }^{28}$ all in all the experience strengthened my understanding of local masculinity immeasurably. My then-husband came to Indonesia with my 11-year-old daughter during this affair, which I put on hold during his twomonth stay. He knew of and was displeased about my relationship, though he had also become involved with someone else in the US. By the time my daughter and I returned home, he and I had agreed to divorce. I moved to Hawaii in 1980, and my paramour came with me for another year, further enhancing my experience of Uma' Jalan masculinity and other community features. Bolton (1995) has written about the 'false dichotomy' the sexual taboo creates between researchers and 'the natives' (p. 140), one that my own experience certainly minimized.

By 1983, when I moved to Sitiung, West Sumatra with my three-year-old son, I had become involved with an American fisheries biologist. He was starting a project on Java, and after a long-distance courtship (Java to Sumatra), we married in 1985. Shortly after that, we were joined by my teenage daughter. My new husband was monogamous by nature and I consciously decided to accept that practice as well. I was also part of a team, initially of three American men (later five) with their families and 10 to 15 Indonesian team members, almost all young, single men from Java. By this time, I was nearing 40, my own sexuality had moderated somewhat, and I was surrounded by religious, agricultural (and fisheries) scientists not-to my knowledge-inclined to social or sexual experimentation. My social context was very different, I was not lonely, nor was I tempted to 'stray'. The cultural system I encountered in Sitiung was also less appealing (and therefore probably less tempting) to me than was that of the egalitarian Kenyah. ${ }^{29}$

The differences in perspective related to these differing life conditions mean that I obtained different kinds of information in the different field sites. The topics of study also differed:

The Bushler Bay study, located in the Olympic National Forest and adjacent to the Olympic National Park, focused on the educational system, as part of a national programme (funded by the National Institute of Education), with one field researcher (all men, except me) in each of ten rural sites across the nation and a cross-site team in Cambridge, Massachusetts studying all ten, also all men. My first husband and I were job-sharing and monitoring what was envisioned initially as experiments in locally planned educational change, though federal involvement reduced local decision-making rather quickly. We were also writing our doctoral dissertations (discussed in Chapter 2, see also e.g., Corwin 1977; Herriott and Gross 1979). 
In Long Segar, East Kalimantan, my project was funded by the US Forest Service, the Man and Biosphere Program of the UN and the Indonesian National Science Foundation (Lembaga Ilmu Pengetahuan). The project involved understanding the 'interactions between people and forests'. We were interested in the practice and ecological effects of swidden agriculture and the Indonesian resettlement programme, and the rationality of local people (which in those days-1979-1980 — was still in question; see Chapter 4). Although I was part of a small, gender-balanced field team, we were spread around Kalimantan and I rarely saw the other team members. My occasional professional interactions were with men from the German Transmigration Area Development project along the rivers, in Long Segar and in the provincial capital, Samarinda, and with professors at Mulawarman University (all men introduced briefly in Chapter 6).

In Sitiung, West Sumatra, our project was funded by USAID and what I call the 'Soils Center' ${ }^{30}$ on Java, managed by 'Island University' in Hawaii and 'Southern State University' in the American South. The project was initially designed to develop acceptable agricultural systems for the transmigrants ${ }^{31}$ who had moved to West Sumatra from Java. We were implementing a participatory approach called 'Farming Systems Research and Development'. Initially we worked only with Javanese and Sundanese transmigrants; in the third year, we began studying and working with the long-resident Minangkabau as well. Our team grew from three to five, with the other researchers all married men. However, most of the spouses had professional capabilities (nutrition, nursing, social work, fisheries biology) and we regularly made use of their skills informally (Chapter 5).

Still married to my second (and current) husband, I began consulting for Forest Research Institute (FRI) in 1994. We moved to its headquarters, where I began as a principal researcher in 1996 and stayed until 2009-I remain a senior associate now. At FRI, my colleagues represented many countries, though the professionals were dominated by researchers from the global North (initially UK, France, Germany, Australia and the US) and support staff from Indonesia (mainly Javanese, Sundanese and Chinese Indonesians). My research focused on issues of people and forests: social aspects of criteria and indicators for sustainable forest management, adaptive collaborative management with forest communities, health and forests, decentralization/devolution of forest management and landscape management. Gender was important throughout. Partnership was ubiquitous, and in such contexts, I also worked with researchers from Africa, Latin America and other parts of Asia. Most were men. I had no more extramarital sexual liaisons.

\section{Flow of this book}

This book is organized chronologically, with the intention of showing the variation from place to place, but also taking the reader on a journey through changes occurring over the last 70 years or so. In Chapter 2, I introduce my own 
childhood, youth and young adulthood (circa 1950-1972). As mentioned previously, this allows the reader to assess for him/herself the likely biases and lenses through which I view masculinity — setting the stage for the chapters to follow, but also providing glimpses of the regional variety in American masculinities. Biophysical scientists will not be accustomed to such disclosure or its relevance. They may choose to skip this chapter. However, the variety of masculinities is further exemplified there. The style in which each subsequent chapter is written differs, reflecting the differing circumstances of the research, the different methods used and perhaps the differing times-but all addressing masculinities in forests.

How I've dealt with anonymity differs from one chapter to the next. In Chapters 3, 6 and parts of 7, I take the need for anonymity seriously. In the other chapters, because of the attitudes of the people involved, I do not. Chapter 2 is quite historical so only occasionally is anonymity important, something I try to honour as needed. In Chapters 4 and 5, people take pride in their cultural systems and would be disappointed to be disguised in a book such as this. In Chapters 1 and 8, there is little in the way of personal information about individuals who might be recognized. In some chapters, where anonymity is important, I disguise some dates by merely indicating the decade. In addition to conventional citations, I include material from my fieldnotes (called 'notes') and from my personal diaries (called 'journals') in the text.

Chapter 3 takes us to a rural American community in the Pacific Northwest in the mid-1970s. Ethnically, the community was almost 100\% white and considered 'under-privileged' by outsiders. ${ }^{32}$ About half of the men were engaged in natural-resource-based private industry (especially logging, the group A. M. Colfer and I called 'Locals') and about half were employed in public institutions (the US Forest Service, the US Park Service, the public school, etc.; 'Public Employees'). This employment-based social structural differentiation accounted for much of the difference in masculinities, with very different harp strings selected by each group. Age also made a difference. Gender differentiation was extreme among Locals, less so among Public Employees. ${ }^{33}$

In Chapter 4, we move to the Indonesia of 1979 and 1980, where we encounter first, and superficially, the Balinese. After two months there, I moved to Long Segar, to a group of Uma' Jalan Kenyah Dayaks (referred to henceforth as 'Kenyah'), whose attitudes and behaviour relating to gender differed even more dramatically from those in the rural American logging community. There were identifiable masculine harp strings, but their significance in daily life was much less marked than in the rural US. And the chords that Kenyah men tended to play drew on different harp strings than those in the US; gender, as social structural and ideational systems, was muted (Ardener 1975).

In Sitiung, West Sumatra (Chapter 5), there was a complex ethnic mix: three Indonesian ethnic groups (Minangkabau, Javanese and a few Sundanese) intersected with professionals from the US (all white men) and Indonesia (also Javanese, Sundanese and Minangkabau) in the mid-1980s. The Minangkabau were 
a matrilineal and strongly Islamic group who practised swidden agroforestry and paddy rice agriculture; the Javanese were bilateral, less overtly religious and focused on farming field crops (rice, corn, soybeans); and the Sundanese, also bilateral but showing more dominance by men and a stronger Islamic orientation, preferred vegetables, fruits and fish farming where feasible. Masculinities differed among these three groups as well as among the Americans.

In Chapter 6, the discussion shifts from formal research results to an analysis based on four decades of personal experience working mostly with an international coterie of what Connell (1995) calls 'Men of Reason' (pp. 164-182). Rather than drawing on studies per se, it relies on my diaries and personal memories of interactions that imply the plucking of particular harp strings and chords.

Chapter 7 is divided into three parts. The first provides a return to the reflexive approach in Chapter 2, bringing the discussion up to the present in rural and forested upstate New York. The second part reports the results of a brief restudy of Bushler Bay in 2017 and the third discusses change among the Kenyah and in their forests, deriving from another brief restudy in 2019.

The conclusions (Chapter 8) summarize important differences in men's links with forests. The differences among Bushler Bay's Locals and Public Employees, the Kenyah Dayaks of East Kalimantan, the Minang, Javanese and Sundanese of West Sumatra and the global forestry elites whose decisions affect such peoples are revisited. I emphasize the implications of these masculinities as they vary by time and place, for forests and forest management.

\section{Notes}

1 Putz and Holbrook (1988) introduce western notions of such habitats thusly:

Say the word jungle and one conjures up a vision of riotous impenetrable vegetation, drenched with steam and mist, teeming with wondrous, unfamiliar, and perhaps dangerous beasts. Say the word jungle again and the view shifts to an idyllic setting of palm trees and jewel like flowers in which the gentle inhabitants live in harmony with their surroundings. A third time and now the tropical forests form the backdrop for scenes of adventure, conquest, and discovery.

2 This excerpt was provided to me by Maureen Reed, who read an earlier draft of this book.

3 Briefly, power relationships based on sex/sexuality; how relationships may be organized and perceived (see also Glossary).

4 Hegemonic masculinity refers to the practices that legitimize men's dominant position in society and justify subordination of women and of men with non-dominant qualities and practices. Initially in the masculinities literature it was discussed as a culturally idealized form of manhood that was socially and hierarchically exclusive, concerned with breadwinning, was anxiety-provoking and differentiated (internally, hierarchically), brutal and violent, pseudo-natural and tough, psychologically contradictory and thus crisis-prone, economically rich and socially sustained, as well as applying to all men (summarized from Donaldson 1993).

5 Noted also by Spall (2016) in Angola: "As in many other contexts in Africa . .., it was not obvious to men in veterans' families which style of masculinity was hegemonic, or if any was" (p. 162). 
6 As Cornwall (2011) also complains of this literature, "We cannot see the men around us, the men who are part of our everyday lives, our friends, our allies in our struggles" (p. 202).

7 I took seriously Dove and Kammen's (2015) injunction to address 'the mundane'.

8 Cornwall, Karioris, and Lindisfarne (2016) note that they had each come of age in different times, shaped by the politics and ideas of the moment. Our intellectual trajectories had taken us along similar paths, but in quite distinct historical times" (p. xiii). Here I recognize that these contextual changes likely also influence my interpretations of masculinities.

9 Here, I use 'identity' to refer to how a person thinks of himself, what elements of his being he values and what differentiates him from others. These also apply to women.

10 These are studies in which data are taken from communities with little or no feedback of information or direct benefit to them.

11 Here, the emphasis is on men's concerns, but of course women's concerns are equally important and must be considered. Forest managers have not traditionally been systematically cognizant of the concerns of either gender.

12 Sundanese are the ethnic group originally from West Java. They also appear briefly in Chapters 5 and 6.

13 The degree to which this analogy can be used to reflect women's lives remains unclear. Here I focus on men, though it will become clear that many of the 'strings' men pluck can also be plucked by women, but often with different meanings culturally.

14 Wikipedia reports a long history of harp usage (which implies men's involvement), with contemporary symbolic connections with, among others, Ireland, the Catholic church and Guinness beer! (https://en.wikipedia.org/wiki/Harp\#As_a_symbol, accessed 26 June 2019).

15 E.g., whereas I found the Javanese in West Sumatra (Chapter 5) to be happy to experiment with and adopt agricultural practices proposed by our agricultural project, they were rigidly devoted to their own health-related beliefs and practices, unwilling to consider 'modern' alternatives.

16 "Heteronormativity refers, in sum, to the myriad ways in which heterosexuality is produced as a natural, unproblematic, taken-for-granted, ordinary phenomenon" (Kitzinger 2005).

17 This discussion has benefitted from Chris Gibson and Susan Paulson's insights.

18 As Connell's (2005) later work notes,

It is desirable to eliminate any usage of hegemonic masculinity as a fixed, transhistorical model. This usage violates the historicity of gender and ignores the massive evidence of change in social definitions of masculinity.

19 This section and the next may be of less interest to biophysical scientists, referring to social science theory and to reflexivity (my personal situation in each field site).

20 In the late 1960s, anthropologists still talked about 'primitive man' and 'peasants'. Using that now-abandoned terminology, this book deals with the 'civilized' (in Bushler Bay and my professional colleagues), the peasantry (the Javanese and Minangkabau) and the 'primitive' (the Kenyah). Understandings and vocabularies have changed.

21 Connell (2005) recognizes three levels of relevance for masculinity: the local, the regional and the global (p. 848). We must also remember Tsing's (2005) analysis of policy implementation, which shows dramatically how broader scale perspectives are altered and adapted locally in Kalimantan (reflecting Gramsci's hegemonic struggles).

22 Apologies to readers less familiar with social science terminology. The next few pages may be more difficult to read.

23 In Connell's (2005) terms, "Hegemony did not mean violence, although it could be supported by force; it meant ascendancy achieved through culture, institutions, and persuasion" (p. 832).

24 A similar meshing of these three elements is discussed by Kahin (1999) regarding the Minangkabau (Chapter 5). 
25 Gibson (2018) does, however, conclude later

that far from it being possible to identify some atemporal, pan-human mode of sociality, no stable mode of sociality or system of values can be identified within the activities of even a single human being.

26 Bolton (1995), a gay man, discusses the taboo on ethnographers engaging in sex in the field (p. 140), and argues persuasively against such a taboo.

27 In considering whether or not to engage in sexual relations with community members, one must balance one's personal system of ethics with one's interest in the deeper knowledge of the particular field setting that intimate relations afford, the potential to minimize the self-'other' distinction, the traditional disapproval of the academic community, potential harm to others, a possible reduction in the 'objectivity' some still consider truly possible in studying culture and one's own views on and experience of sexuality.

28 I later asked her why she forgave me. She said that her husband would have been having affairs with someone else anyway, and his relationship with me had at least resulted in material benefit to the family. I'd contributed to various community projects, sent money when she was ill, helped pay for her daughter in law's education.

29 Some cultures appeal to me more than others. The Kenyah kindness to each other, lack of an ideology of female inferiority, positive spin on hard work and flexible sex roles all appealed to me. At the other extreme was my time in the Sultanate of Oman, where men and women were strictly segregated in almost all realms, women were seen as inferior and dangerous, the initial response to any request was always 'no' and there was a harshness about interpersonal relations that I found difficult.

30 I use pseudonyms as needed throughout this book.

31 Transmigrants are participants in a longstanding Indonesian (and previously Dutch) programme to move people from densely populated Java and Bali to the 'Outer Islands' of Indonesia.

32 Although there are Native American communities on the western side of the Olympic Peninsula, there are none in the area of Bushler Bay, nor did I encounter Native American masculinities on this particular journey.

33 These folks more closely resemble the population imagined/described in much masculinities literature, which includes an assumption of strong gender differentiation and masculine fear of appearing feminine (see Morris and Ratajczak 2019, for a nice summary of such analyses as applied to violence against women).

\section{References}

Altork, Kate. 1995. "Walking the Fire Line: The Erotic Dimension of the Fieldwork Experience." In Taboo: Sex, Identity, and Erotic Subjectivity in Anthropological Fieldwork, edited by Don Kulick and Margaret Willson, 107-139. London and New York: Routledge.

Ardener, E. 1975. "Belief and the Problem of Women.” In Perceiving Women, edited by S. Ardener. London: Malaby Press.

Bolton, Ralph. 1995. "Tricks, Friends and Lovers." In Taboo: Sex, Identity and Erotic Subjectivity in Anthropological Fieldwork, edited by Don Kulick and Margaret Willson, 140-167. New York and London: Routledge.

Colfer, Carol J. Pierce. 2005. The Complex Forest: Communities, Uncertainty, and Adaptive Collaborative Management. Washington, DC: Resources for the Future/CIFOR.

Colfer, Carol J. Pierce. 2018. "Before and After the 'Timber Wars': Context, Change and Potential Collaboration on the Olympic Peninsula." Humboldt Journal of Social Relations 40:137-162. 
Colfer, Carol J. Pierce, and Yvonne Byron. 2001. People Managing Forests: The Links between Human Well-Being and Sustainability. Washington, DC: Resources for the Future/ CIFOR.

Colfer, Carol J. Pierce, and with A. Michael Colfer. 1978. "Inside Bushler Bay: Lifeways in Counterpoint." Rural Sociology 42 (2):204-220.

Colfer, Carol J. Pierce, and Jean-Laurent Pfund, eds. 2011. Collaborative Governance of Tropical Landscapes. London: Earthscan, CIFOR.

Connell, Raewyn W. 1995. Masculinity. Berkeley, CA: University of California Press.

Connell, Raewyn W. 2005. "Hegemonic Masculinity: Rethinking the Concept." Gender and Society 19 (6):829-859. https://doi.org/10.1177/0891243205278639.

Cornwall, Andrea. 2011. "Women's Empowerment: What Do Men Have to Do with It?” In Men and Development: Politicizing Masculinities, edited by Andrea Cornwall, Jerker Edström, and Alan Greig, 196-204. London: Zed Books.

Cornwall, Andrea. 2016. "Introduction: Masculinities under Neoliberalism." In Masculinities under Neoliberalism, edited by Andrea Cornwall, Frank G. Karioris, and Nancy Lindisfarne, 1-28. London: Zed Books.

Cornwall, Andrea, Frank G. Karioris, and Nancy Lindisfarne, eds. 2016. Masculinities under Neoliberalism. London: Zed Books.

Corwin, Ronald G. 1977. Patterns of Federal-Local Relationships in Education: A Case Study of the Rural Experimental Schools Program. Washington, DC: National Institute of Education.

Donaldson, Mike. 1993. "What Is Hegemonic Masculinity?" Theory and Society 22 (5): 643-657.

Dove, Michael R., and Daniel M. Kammen. 2015. Science, Society and the Environment: Applying Anthropology and Physics to Sustainability. London: Routledge.

Elias, Marlène, Netsayi Mudege, Diana E. Lopez, Dina Najjar, Vongai Kandiwa, Joyce Luis, Jummai Yila, Amare Tegbaru, Gaya Ibrahim, Lone Badstue, Esther NjugunaMungai, and Abderahim Bentaibi. 2018. "Gendered Aspirations and Occupations Among Rural Youth, in Agriculture and Beyond: A Cross-regional Perspective." Journal of Gender, Agriculture and Food Security 3 (1):82-107.

Enria, Luisa. 2016. “'I Must Stand Like a Man': Masculinity in Crisis in Post-War Sierra Leone." In Masculinities under Neoliberalism, edited by Andrea Cornwall, Frank G. Karioris, and Nancy Lindisfarne, 136-150. London: Zed Books.

Feldman, Shelley, and Linda Shaw. 2018. "The Epistemological and Ethical Challenges of Archiving and Sharing Qualitative Data." American Behavioral Scientist:1-23. https:// doi.org/10.1177/0002764218796084.

Fine, Cordelia. 2010. Delusions of Gender: How Our Minds, Society and Neurosexism Create Difference. New York: W. W. Norton \& Co.

Ford, Michele, and Lenore Lyons. 2012. "Introduction." In Men and Masculinities in Southeast Asia, edited by Michele Ford and Lenore Lyons, 1-19. New York: Routledge.

Forgacs, David, ed. 2000. The Antonio Gramsci Reader. New York: New York University Press.

Gibson, Thomas. 2005. And the Sun Pursued the Moon: Symbolic Knowledge and Traditional Authority Among the Makassar. Honolulu, HI: University of Hawaii Press.

Gibson, Thomas. n.d. "House, Mosque and School: Androgynous Transformations in South Sulawesi, Indonesia." unpublished:29.

Graham-Davies, Sharyn. 2004. "Hunters, Wedding Mothers, and Androgynous Priests: Conceptualising Gender among Bugis in South Sulawesi, Indonesia.” PhD dissertation, Anthropology and Asian Studies, University of Western Australia.

Herriott, Robert E., and Neal Gross, eds. 1979. The Dynamics of Planned Educational Change: Case Studies and Analyses. Berkeley, CA: McCutchan Publishing Corporation. 
Kabeer, Naila. 1999. "Resources, Agency, Achievements: Reflections on the Measurement of Women's Empowerment." Development and Change 30 (3):435-464. https:// doi.org/10.1111/1467-7660.00125.

Kahin, Audrey. 1999. Rebellion to Integration: West Sumatra and the Indonesian Policy 19261998. Amsterdam, The Netherlands: Amsterdam University Press.

Keeler, Ward. 2017. The Traffic in Hierarchy: Masculinity and Its Others in Buddhist Burma. Honolulu, HI: University of Hawai'i Press.

Killick, Andrew P. 1995. "The Penetrating Intellect: On Being White, Straight and Male in Korea." In Taboo: Sex, Identity and Erotic Subjectivity in Anthropological Fieldwork, edited by Don Kulick and Margaret Willson, 76-106. London and New York: Routledge.

Kitzinger, Celia. 2005. "Heteronormativity in Action: Reproducing the Heterosexual Nuclear Family in After-hours Medical Calls." Social Problems 52 (4):477-498.

Kulick, Don, and Margaret Willson, eds. 1995. Taboo: Sex, Identity and Erotic Subjectivity in Anthropological Fieldwork. London and New York: Routledge.

Larson, Anne M., Therese Dokken, Amy E. Duchelle, Stibniati Atmadja, Ida Ayu Pradnja Resosudarmo, Peter Cronkleton, Marina Cromberg, William Sunderlin, Abdon Awono, and Galia Selaya. 2016. "Gender Gaps in REDD+: Women's Participation is Not Enough." In Gender and Forests: Climate Change, Tenure, Value Chains, and Emerging Issues, edited by Carol J. Pierce Colfer, Bimbika Sijapati Basnett, and Marlene Elias, 68-88. London: Earthscan/Routledge/CIFOR.

Lentz, Linda. 2017. The Compass of Life: Sundanese Lifecycle Rituals and the Status of Muslim Women in Indonesia. Durham, NC: Durham Academic Press.

Little, Jo. 2006. "Gender and Sexuality in Rural Communities." In The Handbook of Rural Studies, edited by Paul Cloke, Terry Marsden, and Patrick Mooney. London: Sage Publications Ltd.

Lugones, Maria. 2007. "Heterosexualism and the Colonial/Modern Gender System." Hypatia 22 (1):186-209.

Mertz, Ole, Daniel Müller, Thomas Sikor, Cornelia Hett, Andreas Heinimann, JeanChristophe Castella, Guillaume Lestrelin, Casey M. Ryan, David S. Reay, Dietrich Schmidt-Vogt, Finn Danielsen, Ida Theilade, Meine van Noordwijk, Louis V. Verchot, Neil D. Burgess, Nicholas J. Berry, Thu Thuy Pham, Peter Messerli, Jianchu $\mathrm{Xu}$, Rasmus Fensholt, Patrick Hostert, Dirk Pflugmacher, Thilde Bech Bruun, Andreas de Neergaard, Klaus Dons, Sonya Dewi, Ervan Rutishauser, and Zhanli Sun. 2012. "The Forgotten D: Challenges of Addressing Forest Degradation in Complex Mosaic Landscapes Under REDD+." Geografisk Tidsskrift-Danish Journal of Geography $112(1): 63-76$.

Morris, Edward W., and Kathleen Ratajczak. 2019. "Critical Masculinity Studies and Research on Violence Against Women: An Assessment of Past Scholarship and Future Directions." Violence Against Women 25 (16). https://doi.org/10.1177/1077801219875827.

Pascoe, C. J. 2007. Dude, You're a Fag: Masculinity and Sexuality in High School. Berkeley, CA: University of California Press.

Paulson, Susan. 2016. Masculinities and Femininities in Latin America's Uneven Development. New York and London: Routledge.

Petesch, Patti, Renee Bullock, Shelley Feldman, Lone Badstue, Anne Rietveld, Wenda Bauchspies, Adelbertus Kamanzi, Amare Tegbaru, and Jummai Yila. 2018. "Local Normative Climate Shaping Agency and Agricultural Livelihoods in Sub-Saharan Africa." Journal of Gender, Agriculture and Food Security 3 (1):108-130.

Pini, Barbara, Berit Brandth, and Jo Little, eds. 2015. Feminisms and Ruralities. Lanham, MD: Lexington Books. 
Putz, Francis E., and N. Michele Holbrook. 1988. "Tropical Rainforest Images." In People of the Tropical Rain Forest, edited by Julie Sloane Denslow and Christine Padoch, 37-52. Berkeley, CA: University of California Press.

Redfield, Robert. 1960. Peasant Society and Culture. Chicago, IL: University of Chicago Press. Saini, Angela. 2017. Inferior: How Science Got Women Wrong-And the New Research That's Rewriting the Story. Boston, MA: Beacon Press.

Sayer, Jeffrey, Terry Sunderland, Jaboury Ghazoul, Jean-Laurent Pfund, Douglas Sheil, Erik Meijaard, Michelle Venter, Agni Klintuni Boedhihartono, Michael Day, Claude Garcia, Cora van Oosten, and Louise E. Buck. 2013. “Ten Principles for a Landscape Approach to Reconciling Agriculture, Conservation, and Other Competing Land Uses." PNAS 110 (21):8349-8356.

Schneebaum, Tobias. 2003. Wild Man. Madison, WI: University of Wisconsin Press.

Spall, John. 2016. "Fatherhood and Intergenerational Struggles in the Construction of Masculinities in Huambo, Angola." In Masculinities Under Neoliberalism, edited by Andrea Cornwall, Frank G. Karioris, and Nancy Lindisfarne, 151-164. London: Zed Books.

Sutlive, Vinson H., ed. 1991. Female and Male in Borneo: Contributions and Challenges to Gender Studies. Williamsburg, VA: The Borneo Research Council, Inc.

Tsing, Anna Lowenhaupt. 2005. Friction: An Ethnography of Global Connection. Princeton, NJ: Princeton University Press.

von Benda-Beckmann, Keebet. 2009. "Balancing Islam, Adat and the State: Comparing Islamic and Civil Courts in Indonesia." In The Power of Law in the Transnational World: Anthropological Enquiries, edited by Franz von Benda-Beckmann, Keebet von BendaBeckmann, and Anne Griffiths, 216-235. New York: Berghahn Books. 